\title{
THE ETHICS OF RESEARCH RELATED TO HEALTHCARE IN DEVELOPING COUNTRIES
}

\author{
Keith McAdam*
}

\begin{abstract}
In April 2002 the Nuffield Council on Bioethics published the Report The Ethics of Research Related to Healthcare in Developing Countries. It provides an ethical framework for those designing or conducting healthcarerelated research in developing countries. This paper will draw on the conclusions made in the Report, and present some of the recommendations. It will cover the importance of genuine consent, standards of care and ethical review of research. The focus will be on what happens when research is over and benefits to the community. The Report concludes that rigorous safeguards must be in place to prevent the exploitation of those who take part in externally-sponsored research.
\end{abstract}

Key Words: Informed consent, ethics, research, community benefits

\section{LA ÉTICA DE LA INVESTIGACIÓN RELACIONADA CON LA ATENCIÓN DE SALUD EN LOS PAÍSES EN DESARROLLO}

Resumen: En Abril del 2002, el Nuffield Council on Bioethics publicó el Informe sobre la ética de la investigación relativa al cuidado de la salud en países en desarrollo, que proporciona una base ética para quienes diseñan o realizan investigación en salud en estos países. Este artículo se basa en las conclusiones de este informe y presenta algunas de las recomendaciones. Cubre la importancia del consentimiento informado genuino, estándares del cuidado de la salud y evaluación ética de la investigación. Se enfoca en lo que sucede cuando la investigación finaliza y en los beneficios para la comunidad. El informe concluye que se debe disponer de una rigurosa protección para prevenir la explotación de aquellos que participan en una investigación patrocinada externamente.

Palabras clave: Consentimiento informado, ética, investigación, beneficios para la comunidad

\section{A ÉTICA DA PESQUISA RELACIONADA COM O CUIDADO DE SAÚDE NOS PAÍSES EM DESENVOLVIMENTO}

Resumo: Em abril de 2002, o Nuffield Council on Bioethics publicou o Informe sobre a ética da pesquisa relacionada ao cuidado da saúde em países em desenvolvimento. Este Informe nos oferece uma base ética para quem realiza pesquisa em saúde nos países em desenvolvimento. Este artigo se baseia nas conclusões deste informe e apresenta algumas das recomendações. Abarca a importância do consentimento informado genuíno, standards de cuidado de saúde e avaliação ética da pesquisa. Enfoca o que acontece quando a pesquisa termina e nos benefícios para a comunidade. O informe conclui que deve-se dispor de uma rigorosa proteção para prevenir a explotação dos participantes da pesquisa com patrocínio do exterior.

Palavras chave: Consentimento informado, ética, pesquisa, benefícios para a comunidade

Member of Working Party on the ethics of research related to healthcare in developing countries; Professor of Clinical Tropical Medicine, London School of Hygiene and Tropical Medicine; Director, Medical Research Council (UK) Laboratories, The Gambia $1995-2003$.

Correspondence: bioethics@nuffieldfoundation.org 
The Nuffield Council on Bioethics is an independent body that examines ethical questions raised by recent advances in biological and medical research. The Council seeks to play a role in contributing to policy-making and stimulating debate in bioethics. Established in 1991, the Council is funded by the Nuffield Foundation, the UK Medical Research Council and the Wellcome Trust ${ }^{1}$.

In February 1999 the Council held an international workshop on the ethics of clinical research in developing countries. This workshop was set up partly in response to recent international controversies surrounding HIV research in Thailand and Africa. There has also been a significant increase in the amount of externallysponsored research related to healthcare in developing countries. Many of the issues raised by such research, such as the kind of treatment that should be provided to participants following a trial, are not confined to research in developing countries. They tend, however, to be exacerbated when only very limited resources are available, as may be the case in developing countries where basic healthcare is not widely available and research ethics committees are often underdeveloped or absent.

The workshop led to the publication of a discussion paper. The Council then decided that the topic was a matter of such importance that a Working Party should be established to consider it in more detail. The Working Party, chaired by Professor Sir Ken Calman, had a global perspective with members drawn from a number of countries, including Ghana,

The Nuffield Council has published eight major reports on ethical issues associated with: genetic screening; ownership of tissue; xenotransplantation; genetics and mental disorders; genetically modified crops; research related to healthcare in developing countries; genetics and human behaviour, and pharmacogenetics. The Council has also published two discussion papers dealing with ethical issues raised respectively by research on human stem cells and the patenting of DNA.
Uganda, The Gambia, India, Brazil, Denmark and the UK. The group, of which I was a member, met nine times over 21 months, and held several fact-finding meetings, in India, the United States, and at an international meeting in Oxford. We also held a public consultation exercise, during which we received 70 responses from 20 different countries.

The terms of reference of the Working Party were to review the importance of externallysponsored research in developing countries, and to identify and consider the ethical and social implications of conducting such research. This included discussing who benefits from the research; consent; differences in cultural values; differences in levels of healthcare between countries; compatibility of ethical guidelines produced by international bodies; the respective responsibilities of local and non-local ethics review bodies and mechanisms for review and monitoring; and follow-up, including the possible implementation of findings, after the completion of research.

The resulting Report, The Ethics of Research Related to Healthcare in Developing Countries, was published in April 2002². I am going to present today some of the recommendations and main conclusions that we reached.

Developing countries urgently need research to help relieve the enormous burden of disease they carry, including diseases such as TB and malaria. But many countries have limited funds and a lack of trained staff to conduct their own research. Each year £35-40 billion is spent on healthcare research worldwide but only $10 \%$ of this sum is devoted to the health problems of $90 \%$ of the world's population. It is vital that both the public and private sectors in developed countries should

The report is available from the Council's website: www.nuffieldbioethics.org 
sponsor research to help bridge the gap. However, external sponsors differ in their motives for conducting research in developing countries. It is therefore important that all countries set their own national priorities for research into healthcare. When externally-sponsored research is proposed which falls outside national priorities, its relevance must be justified to the appropriate research ethics committees.

Inequalities in resources, between external sponsors and those in developing countries, will often be so great that there is a real risk of exploitation. One of the main conclusions of the Report was that there must be rigorous safeguards in place to protect vulnerable individuals and communities who take part in externally-sponsored research. We realised it would be impossible to formulate a robust set of guidelines for all situations, because local and cultural contexts must also be taken into account. However, our recommendations provide an ethical framework for anyone who is designing or conducting research in developing countries. We have tried to identify the minimum requirements which must be met in all circumstances.

The ethical framework used in the Report is based on four principles: the duty to alleviate suffering; the duty to show respect for persons, the duty to be sensitive to cultural differences; and the duty not to exploit the vulnerable. It is crucial that these duties are respected when research is planned and conducted. But when applying these principles it is also critically important that social, cultural and economic context should also be taken into account.

There is no shortage of national and international guidelines that regulate the conduct of healthcare research, including the WMA's Declaration of Helsinki and the CIOMS International Ethical Guidelines for Biomedical re- search involving Human Subjects among many. However, in practice, researchers and sponsors are confronted with guidance that is often generalised and sometimes ambiguous. We considered it important to encourage countries to produce their own national guidance for the clear application of international codes and regulations. More specifically, any new or revised guidance should require the provision of training in the ethical conduct of research for all professionals involved. Training in interpreting and applying research guidance is an important accompaniment to the guidance itself.

We identified a number of pressing issues in the planning of externally-sponsored research. These included consent, standards of care, ethical review of research and what happens when research is over. I will turn to each of these briefly now, before focusing on the question of what should happen after the research is over and the community benefits of research.

\section{Genuine consent}

Misunderstandings can occur when sponsors of research are unfamiliar with the cultural traditions of the country in which it is conducted. Researchers are often faced with difficult choices when considering who should make decisions about taking part in the research. For example, in some communities it is customary for senior members of the family to make decisions on behalf of wives and children. It is crucial to be sensitive to cultural differences, and the Working Party therefore recommended that in some cultural contexts it may be necessary to obtain agreement from the particular community or assent from a senior family member, before any prospective participant in research is approached. However, there is also a duty to show respect for persons, and it is therefore important to insist that each participant must also individually consent to take part. The ethically significant 
requirement is that consent must be genuine, which means that it must be both voluntary and informed. Health professionals must do their best to communicate information accurately and in an understandable and appropriate way. Information forms which are long, complex and inappropriate for the cultural context are more likely to confuse than to inform.

We must also recognise that in some situations it may be inappropriate to ask participants to sign consent forms. An obvious example is if research is being conducted in an illiterate population. In these circumstances, participants could be asked to give verbal consent. Researchers should also consider an appropriate procedure for witnessing the consent. The consent process and information to be provided should always be approved by a research ethics committee.

Participants in research in developing and developed countries have a range of motivations for taking part in research. The point at which inducements become inappropriate is not always clear. Participants should, at the very least, not be placed in a worse position by participating in research. We suggested that, when assessing the acceptability of inducements, researchers should pay particular attention to the potential risks to the participants' health from taking part in the research; whether the incentive being offered is in proportion to the risks and costs to the participants; and whether guaranteeing substantial benefits for taking part in research is more likely to constitute an undue inducement because prospective participants are especially vulnerable. Decisions will need to be justified to local research ethics committees.

\section{Standards of care}

A particularly controversial issue, which has prompted international debate, concerns the standard of care that is provided to members of a control group during research. The Working Party recommended that wherever appropriate, participants in the control group should be offered a universal standard of care. This term refers to the best treatment available anywhere in the world, by contrast with non-universal standard of care, referring to treatment available in a defined region. However, there might be cases where provision of a universal standard is not appropriate. It may not always be deliverable -if the universal standard of care was a liver transplant, for example. Alternatively, the use of a universal standard of care may not give relevant results. It may not, for instance, be appropriate to evaluate a new treatment against one that is too expensive to purchase and too complicated to deliver in a particular country. There can also be cases where the treatment being evaluated may be much more effective than the currently available treatment, but where this might not be demonstrated by research using the universal standard for the control group. In these instances, the challenge is to fulfil the duty to undertake research in a way that is consistent with the principle of not exploiting those who are vulnerable. We recommended that the minimum that should be offered to research participants is the best intervention currently available as part of the national public health system. In certain well considered situations, exceptions to this recommendation may be justified, for example where research attempts to establish the ineffectiveness of what currently is deemed to be the best treatment available through the host's country health system, by comparing it to a placebo.

In determining the appropriate standard of care to be provided to participants, the Working Party recommended that a number of factors be considered by sponsors, researchers and research ethics committees. These include:

- the appropriate research design to answer the research question, 
- the seriousness of the disease and the effect of proven treatments,

- the existence of a universal standard of care for the disease,

- the standard of care in the host and sponsoring countries,

- the standard of care which can be afforded by the host and sponsoring country for the disease being studied,

- the standard of care which can effectively be delivered in the host country during research, and

- the standard of care which can be provided in the host country on a sustainable basis.

\section{Ethical review of research}

Effective ethical review of research provides a crucial safeguard for research participants, and all countries should establish an effective system. We recommended that externally-sponsored research projects must be reviewed locally. Funders should ensure that the study they are funding has been reviewed by a sufficiently diligent process, which assesses the scientific validity and ethical acceptability, as well as the relevance to priorities in healthcare within the country. Committees which do not have adequate funding to cover their costs may set fees for review. However, it is vital that the independence of research ethics committees be maintained. We therefore emphasised the need for creative approaches to providing support, without compromising their independence. We recommended that all sponsors should be responsible for meeting the costs of reviewing externally-sponsored research and that they should ensure that the funds are used in an ethically acceptable way.

\section{What happens once the research is over?}

Many controversies concern the question of what happens when research is over. Is it ethically acceptable to conduct research into a form of treatment in a country that may not be able to afford to provide it? This is not a straightforward issue. For example, the price of treatments can drop dramatically after research, or an agreement may be reached with a pharmaceutical company that the treatment will be provided for free for a certain period.

Researchers, sponsors and research ethics committees have to consider whether a successful intervention should be provided to three groups of people: members of the control group in a trial, all of the participants in the research project, and the wider community in which the research took place. The principle that those in the control arm of a trial should be provided with the intervention when it has been demonstrated to be efficacious is widely acknowledged. We also concluded that it is not ethically acceptable for any study to begin without a decision having been made about whether or not those in control groups will be offered an intervention shown to be successful on completion of the trial, where relevant and appropriate. Participants should be informed of the decision as part of the process of obtaining their consent.

With regards the provision of an intervention to all participants once a study is over, the revised Helsinki Declaration states that every participant should be assured of access to the best proven prophylactic, diagnostic and therapeutic methods that have been identified in the study. There has been continued debate over this and the WMA have set up a Working Party to consider it further. However, guaranteeing the provision of an intervention may not always be possible, especially in relation to treatment for chronic disease. We emphasised that it is 
important that the issues be considered at the planning stage of any research, rather than debated or negotiated at the end of the study. We suggest that researchers should endeavour, before the beginning of a trial, to secure post-trial access for effective interventions for all participants.

A most contentious issue is the availability of successful interventions to the wider community once research is over. Several questions arise, with respect to the range and scope of the responsibilities, and on whom such responsibilities fall:

- Should provision of an effective treatment be limited to the participants in research, or extended to others in the wider community after research? If the latter, by whom?

- How effective must an intervention be shown to be to merit provision?

- Should all with a perceived need in the country receive the intervention? If so, for how long and who should provide it?

Many social, political and economic factors will influence the likely availability of a treatment shown to be successful and not all of these can be anticipated. It is also important to remember that, in reality, a single research study will only rarely lead to the discovery of a new intervention that can be introduced promptly into routine care. There is also likely to be a need for further research to define the place of the new intervention in the healthcare system and the feasibility of introducing it. The trial may need to be repeated elsewhere and in a different setting. However, the issue of whether a new treatment could be introduced and maintained in the wider community should be considered before research is conducted, and there will need to be negotiations between the various interested parties.
Researchers have some responsibility in these discussions but there is disagreement about how far that responsibility extends. Researchers are generally not in a position to translate their findings into action. However, they can draw attention to problems which have been neglected, or conditions whose impact has been underestimated, and demonstrate that there are feasible solutions.

Sponsors, national healthcare authorities, international agencies and research ethics committees must also be involved. If sponsors were required to fund the future provision of effective interventions, the majority would no longer support such research. Provision of a successful intervention to the wider community is primarily the responsibility of governments, although there have been contributions from the pharmaceutical industry. We concluded that the complexity of the circumstances relating to the availability of interventions after the completion of a trial makes it difficult to formulate general guidance which applies to all different forms of interventions. However, there is a duty on researchers to address the issue before any research is initiated, and investigators must justify to the relevant research ethics committee why the research should be carried out if it is not thought possible to make a new intervention available to some or all of the host country population.

Another issue arises after the research if participants suffer an adverse effect as a consequence of the trial. Clearly, during the study the researchers have a responsibility to care for those who may suffer such adverse effects arising from the research. But in our view, this responsibility extends also to those who suffer such adverse effects after the trial is formally ended, and to those who suffer the chronic consequences of adverse effects experienced during the study. The question of compensation for 
those injured or placed at increased risk of harm in the future as a result of research also needs to be addressed before the research begins.

One real contribution which researchers and sponsors may be able to make is to increase the number of people able to contribute to healthcare and to assist the development of their skills and expertise so that there is some potential for a sustained improvement in healthcare services after the study is completed. The expertise to undertake research at local level is severely limited, with insufficiently trained personnel and a lack of a critical mass of researchers. It is very important that research in developing countries is used as a platform for enhancing the skills of scientists in the local communities, and there is a need to promote genuine partnerships to strengthen expertise in research and institutional development. We recommended that the development of expertise in healthcare and research should be an integral component of all research in developing countries. Sponsors should ensure provision for education and training in ethics of all professionals involved in research. 